\title{
Single currency and regional integration in the ECOWAS region: A new estimation technique using the Pseudo Maximum Likelihood Poisson with High Dimensional Fixed Effects (PPMLHDFE).
}

MICHAEL KOUADIO N'GUESSAN ( $\sim$ michaelnguessann@gmail.com ) PANAFRICAN UNIVERSITY OF YAOUNDE

\section{Method Article}

Keywords: Single currency, flexible exchange rate, regional integration, gravity model, PPMLHDFE

Posted Date: December 22nd, 2021

DOI: https://doi.org/10.21203/rs.3.rs-1193043/v1

License: (9) This work is licensed under a Creative Commons Attribution 4.0 International License. Read Full License 
Title: Single currency and regional integration in the ECOWAS region: A new estimation technique using the Pseudo Maximum Likelihood Poisson with High Dimensional Fixed Effects (PPMLHDFE).

\title{
AUTHOR: MICHAEL KOUADIO N'GUESSAN
}

Student at the

Institute of governance, humanities and social Sciences / Pan African University of Yaoundé_Cameroon

POBox 5383 Yaoundé_Cameroon

michaelnguessann@gmail.com

\begin{abstract}
The progress of regional integration in ECOWAS is leading to the desire to create an optimal monetary zone. This desire to create an optimal monetary zone is leading to a wave of divergent views on the effect and exchange rate regime of the single currency on trade. On the one hand, WAMZ countries want to adopt it with a flexible exchange rate, while on the other hand, WAEMU countries want to adopt it with a fixed exchange rate pegged to the euro. This divergence of views is at the heart of our problem. We need to analyze the effect of this currency and its flexible exchange rate regime on regional integration, more particularly the market integration of the Economic Community of West African States. Our evaluation is based on an augmented gravity model as the basic theoretical model, with the Pseudo Maximum Poisson Likelihood with High Dimension Fixed Effects (PPMHDFE) as the estimation method. This panel study is based on data from the World Bank (WDI), IMF (DOTS) and CEPII from 2009 to 2018. The question addressed by the analysis of the potential effect of sharing a single currency on integration by the ECOWAS market, allows us to arrive at two main results. (i) The potential effect of the single currency on trade is significant, robustness tests confirm the positive effect of currency sharing on trade. (ii) The flexible exchange rate has positive effects on trade. Thus, we therefore call on the political leaders of ECOWAS countries to make efforts to meet the convergence criteria and the establishment of this single currency in order to be the foundation of the single African currency, on the one hand. On the other hand, we recommend the adoption of a single currency with a variable exchange rate with a gradual approach.
\end{abstract}

Keywords: Single currency, flexible exchange rate, regional integration, gravity model, PPMLHDFE 


\section{INTRODUCTION}

Since the 1960s, African States stated the necessity of regional integration in the founding acts of continental community institutions. The Lagos Plan of Action (1980), accelerating the regional dynamics of structured development, suggests the consolidation of regional economic integration organizations. The establishment of the African Economic Community (AEC) in 1991 and the dissolution of the Organization of African Unity (OAU) to form the African Union (AU) in 2002 result from this rationality. As a result, since the 2000s, ECOWAS countries have been suggesting their desire to accelerate the monetary integration process began in the early 1980s, in order to consolidate the regional integration and to stimulate the trade. This has taken the form of a plan to create a single currency in two stages in West Africa. In its first stage, the plan expected the launch of a single currency, the Eco, by the member countries of the West African Monetary Zone (WAMZ) in January 2015. In a second stage, WAMZ expected to merge with the West African Monetary Union (WAMU) to create a single currency for all fifteenth ECOWAS member countries by 2020.

Regional integration is a concept that has been discussing through many political and socioeconomic debates in the world, and even more in Africa. Although its definition seems to be unanimous, it includes several aspects (economic, social, etc.). Consequent, according to Bela (Balassa, B., 1961), regional economic integration is both a dynamic and static phenomenon that must be considered as a process as well as a state of affairs. A process leads to the gradual elimination of different discriminatory practices and a state of affairs that is characterized by the absence of such practices. Regional integration can be defined as "measures taken by governments to liberalize or facilitate trade within region " according to the World Trade Organization (2015).

Integration involves some sharing of sovereignty through the sharing of established regional institutional procedures. It gives preference to the group as a community while pursuing an ultimate goal of institutional merger. It may involve various areas of the state, including sustainable management of the economic environment, also security, human rights, education, health, research and technology or natural resources management (Lavergne, P., and Rostow, 1997). Money is any asset that is generally accepted as payment for goods and services or repayment of debts, and is distinct from both wealth and income (Mishkin, F., 2013). It is unique when it shared with several states and replaces the national currencies (Bakoup and Ndoye, 2016). 
The Economic Commission for Africa (2016) assessments of the Abuja Treaty in 2015 put ECOWAS in a customs union stage, with the occurrence of delays in the implementation of the regional integration process undertaken and a slowdown in the process. According to UNCTAD (2016), it has low integration indexes, namely the trade integration index (0.442), the regional infrastructure index (0.426) and a productive integration index (0.265), compared to the $\mathrm{EAC}^{1}$ and $\mathrm{AMU}^{2}$ whose trade integration indexes are respectively $(0.780)$ and $(0.631)$, then the productive integration indexes are successively (0.553) and (0.481). These low indexes, with regard to the trade component of integration, lead to a weakness in trade within ECOWAS countries, which is mainly based on commodities such as cocoa, coffee, oil, cotton, etc.

Indeed, this regional trade accounts for less than $10 \%$ of the region's total exports and the cumulative value of its imports amounted to $\$ 98.1$ billion, representing about $0.59 \%$ of the total value of world imports. In sum, the total value of ECOWAS trade in goods (sum of exports and imports) estimated at $\$ 190$ billion, while regional trade accounted for only $\$ 19.1$ billion, or about $10 \%$ of total trade volume. On a worldwide scale, they only represent $0.7 \%$ of world exports and $0.5 \%$ of imports, deepening the marginalization of the continent and the ECOWAS area in particular with respect to world trade, over time compared to WAEMU countries. Trade between these countries reflect a greater dynamism than intra-ECOWAS trade, with $15.2 \%$ of total exports and $9.3 \%$ of total imports and this is due to the difference in currencies (UNCTAD, 2018).

This low level of intra-regional trade is an impediment to the potential gains of a monetary union. This idea debated according to two approaches. The first, so-called traditional approach, states that the decision to create (or enter) a monetary union depends on the expected positive externalities. The second, so-called endogenous approach, argues that monetary union acts as a subsidy to the bilateral trade of the countries that have adopted it. Clearly, monetary unification increases the volume of trade (Frankel and Rose, 2002; Sadeh, 2014; Glick and Rose, 2016; Mignamissi, D., 2018). While for Rose (2000) it intensifies market integration, for SantanaGallego and Jorge (2019), exchange rate volatility is not a determinant of trade volumes or even its volatility has a negative effect on trade (Miron et al, 2013).

Much empirical studies has justified the positive link between single currency sharing and trade intensification. Nevertheless, it raises doubts about the existence of such link for a future

\footnotetext{
${ }^{1}$ East African Community

${ }^{2}$ Arab Maghreb Union
} 
currency union, especially when we consider the debates on the feasibility of the monetary union with regard to divergence views point on the adoption of the exchange regime, security crisis and the failure de comply with the convergence criteria.

Theoretically, a divergence of views between the two countries could be a cause for concern, but it is not clear whether it would be possible to achieve a monetary union. From a theoretical standpoint, there is a divergence of views between the exogenous paradigm and the endogenous paradigm of the theory of optimal currency zones ${ }^{3}(\mathrm{OMZ})$. For the feasibility of a single currency, the former requires compliance with the economic criteria of the OMZs, and a good level of convergence of the economies (Mundell, 1961; McKinnon, 1963; Kenen, P. B., 1969; etc.). The second raises a debate opposing the thesis of the virtuous circle of the $\mathrm{OMZs}^{4}$ (Frankel and Rose, 1998; Rose, 2000) and the thesis of the vicious circle of the OMZs ${ }^{5}$ (Krugman, 1993). Thus, for Tsangarides and Qureshi (2008), endogenous mechanisms can cause over time to make sharing a single currency beneficial.

The regional integration's process to which adding the problem of several currencies ${ }^{6}$, coupled with the project of adopting the single currency such as the ECOWAS zone, as well as the nature of its exchange rate regime towards other currencies. It therefore requires looking at the potential effects and the exchange rate regime of such currency on regional integration in this REC. Indeed, while for some, the single currency intensifies trade, for others bilateral trade reacts significantly positively to currency parity (Dorn et al., 2013) or even its volatility has an intuitively significant negative effect on trade ( Miron et al., 2013). What are the effects of a single currency on regional integration in the ECOWAS region? The main objective of this paper is to analyze the effect of the single currency and exchange rate variability on regional integration in the ECOWAS region.

In the analysis of bilateral trade flows, the gravity model is the most widely used. Indeed, it allows us to analyze the effect of the model's variables on trade volumes. To achieve this analysis, unlike Santos Silva and Tenreyro (2006; 2010; 2011) who recommend using a Pseudo-

\footnotetext{
${ }^{3}$ An optimal currency area (OCA or OMZ) is a geographical region within it would be beneficial to establish a single currency (Mundell, 1961).

${ }^{4}$ The adoption of a common currency would increase trade between the partners and thus promote the synchronization of their business cycles (cycle synchronization and the shocks affecting these countries are essentially symmetric shocks): Frankel and Rose's virtuous circle 1998).

${ }^{5}$ Krugman (1993) states that when countries are in a monetary union and specialize according to their comparative advantages and geographical position, trade between these countries is weak, there are divergent cycles and these countries are affected by asymmetric shocks. He illustrates this with the case of the United States, where economically integrated areas are characterized by strong regional specialization that generates asymmetries ${ }^{6}$ Annex
} 
Maximum Likelihood Poisson estimator (PPML), due to high dimensional fixed effects panels; we use the new and more robust estimation technique developed by Sergio Correia et al. (2019) "high-dimensional fixed-effects Pseudo-Maximum Likelihood Poisson estimator". This work will contribute to the empirical literature on the effects of a monetary union on trade in general and specifically in ECOWAS countries. It will bring out the economic policy implications of consolidating the monetary union and increasing trade. Following this introduction, the rest of the paper structures in four sections. Section 1 concerns the literature's review. Section 2 presents the stylized facts of ECOWAS trade. Section 3 deals with the empirical strategy and Section 4 presents the discussion of the results and policy implications

\section{Section 1 - Review of the Literature}

Many economists agree that mutual trade and economic openness increase between countries that share a single currency, due to lower transaction costs and a stable exchange rate regime. In addition, in the empirical literature, there is a broad consensus that a monetary union increases the volume of trade between the countries involved. Some recent studies find out a significant positive relationship between a currency union and trade, while others find a mixed result. This work has followed two lines of inquiry.

The first, which follows the logic of Rose (2000), assesses the direct effect of currency unions on integration through trade. Using a panel data study covering 186 countries over the period 1970-1990, she showed that a currency union triples the volume of trade on average. According to Glick and Rose (2016), using the gravity model, although the currency union increases the trade of countries involved about 50\%; it still has different effects on the trade of some countries in the European Union. For Mignamissi (2018), the potential effect of the single currency on bilateral trade is positive and significant, but it differs across communities because of the characteristics of member countries. Thus, for Sadeh (2014), the euro, in addition to intensifying trade between the countries of the European Union, would have increased the trade of European countries that are not members of the euro zone by 35\%. Studies of Qing He and al. (2019) using a gravity model, also result in the fact that monetary integration increases intraregional trade. Moreover, the relationship between currency and trade varies with the number of member countries in the currency union and the differences in economic development of member countries. 
The second axis focuses attention on the effect of monetary regimes and policies on trade $^{7}$ through an assessment of the effect of change in monetary regime on trade. It also estimates the determinants of bilateral exports. This axis shows that the positive and significant effect of monetary integration on bilateral trade weakened by the complexity of political regimes, especially as the ECOWAS space coupled with a series of elections. Other recent studies have examined the link between the single currency and trade according to Anyanwu (2003). These researches, based on an exogenous analysis, show that the African franc zone is not optimal, but tend to validate its optimality according to the endogenous approach ${ }^{8}$. Some recent research globally confirm the existence of endogenous effects of a single currency Couharde and al (2013). To these two axes, another synthesis debate concerns the variability of the exchange rate. Indeed, several authors have also analyzed the impact of the exchange rate regime on trade. We quote among others (Dorn, Peter and Egger H, 2013; Miron et al, 2013). For the formers, bilateral trade responds significantly and positively to currency parity, but only after at least 8 years and remains constant thereafter. As for Miron and al (2013), exchange rate volatility has an intuitively significant negative effect on trade while the common currency has a positive effect. Finally, studies of Santana-Gallegos and Pérez-Rodríguez (2019) show that exchange rate volatility is not a determinant of trade volumes. Indeed, for them, exchange rate volatility does not positively influence trade because; it constitutes an important mean for the crisis transmissions.

\section{Section 2: The stylized facts}

According to the literature on currency areas and regional integration, countries with large trade flows are more likely to form an optimal currency union, thanks in part to low transaction costs. Thus, regional integration offers unique opportunities to carry out the transformation and development of a sub-regional space. This integration faces certain obstacles. These obstacles limit trade. These include tariff and non-tariff barriers of trade, increased competition between countries due to low trade complementarity, and obstacles to the free movement of factors of production. However, like most regional integration mechanisms in Africa, ECOWAS and WAEMU have focused primarily on border measures and tariffs that have significantly hampered all integration efforts.

\footnotetext{
${ }^{7}$ Hove S., A. Touna Mama, F. Tchana Tchana, (2015); Lafuente, J. A., R. Perez and J. Ruiz, (2016)

${ }^{8}$ Agbodji (2007); Zhao,and Kim (2009)
} 
Regional integration has several aspects. In the context of our research, the trade component is the one we are interested in because of the weakness of intra-community trade due to linguistic and cultural barriers within ECOWAS countries, the low level of diversification of member states' production, and the relative weakness of infrastructure (transport, energy) and the nonconsolidation of the common external tariff.

According to the index of Regional Integration in Africa (UNCTAD, 2016), SADC has an overall score of (0.531) higher than ECOWAS (0.509). As trade integration is a regional priority for all RECs, according to UNCTAD ${ }^{9}$ (2016), ECOWAS also has a low score (0.531) in this area. ECOWAS also has a low trade integration index score (0.442), below the average of the eight RECs (0.540), compared to the EAC (0.780), and AMU (0.631).In addition to this low level of trade integration index, there are non-tariff measures (NTMs), including domestic measures. These measures, which are more important than customs duties, also slow down intra-regional trade, as they considerably increase the cost of doing business (WTO ${ }^{10}, 2011$ ). The persistence of non-tariff barriers (NTBs) further hinder Intra-ECOWAS trade, particularly quantitative restrictions. These NTMs disproportionately and negatively affect small countries and producers. The total value of ECOWAS trade in goods (sum of exports and imports) estimated at $\$ 190$ billion in 2015, while regional trade accounted for only $\$ 19.1$ billion, or about $10 \%$ of total trade volume (Figure 1).

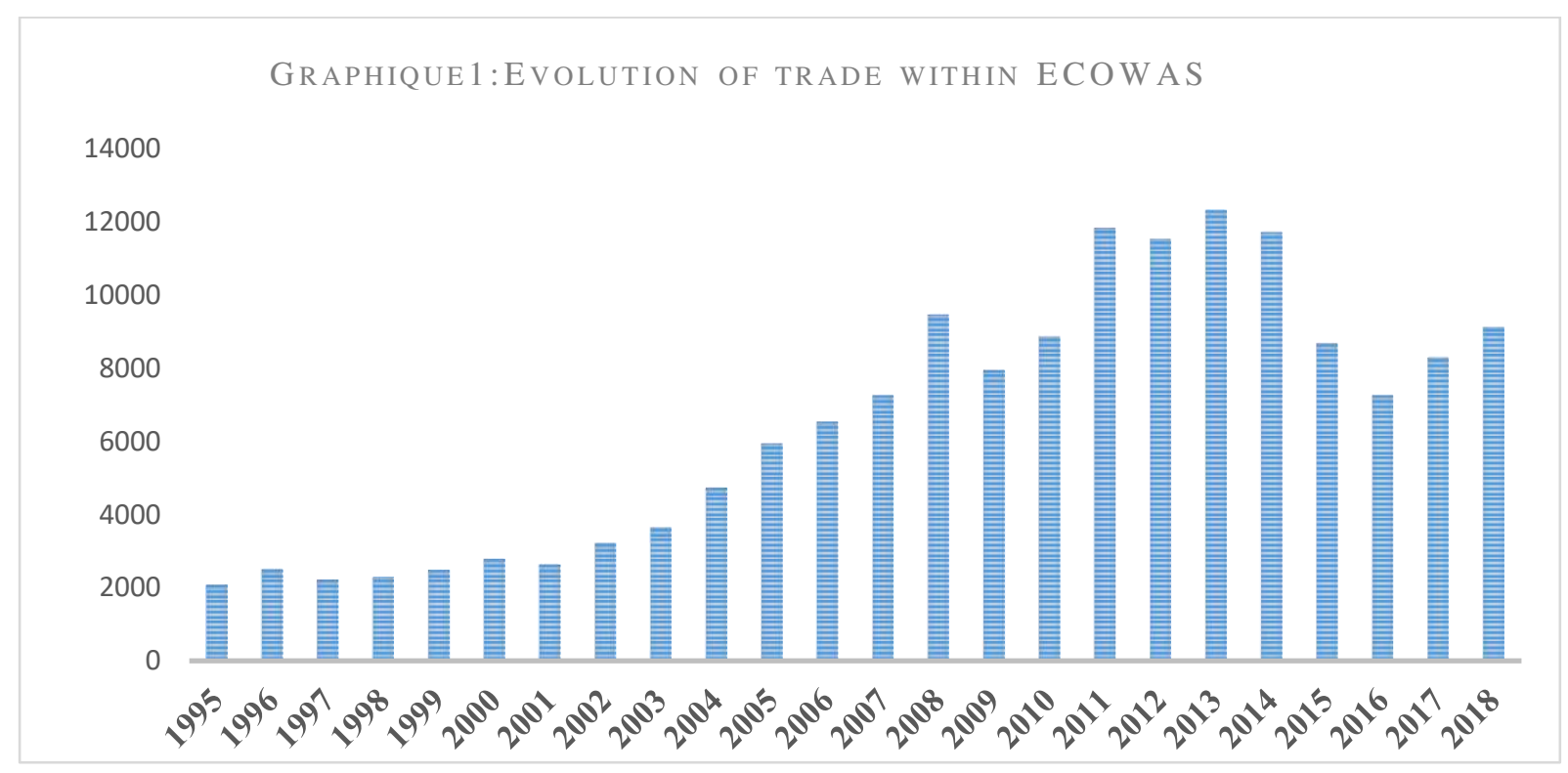

Source: Author, based on UNCTADSTAT data

\footnotetext{
${ }^{9}$ United Nations Conference on Trade and Development

${ }^{10}$ World Trade Organization
} 
This trade is essentially dominated by four (04) of the fifteen (15) member states (Nigeria, Côte d'Ivoire, Ghana and Senegal), which account for a large share of intra-community trade. Indeed, these four countries respectively account for $83.3 \%$ and $63.6 \%$ of intra-community exports and imports. For Mignamissi (2018), ECOWAS represents a low weight in trade with $9.15 \%$ of intra exports in the total, compared to regions such as ASEAN, NAFTA ${ }^{11}$ and the EU that trade with each other at $34.47 \%, 51.38 \%$ and $65.18 \%$ respectively for exports, and $43.48 \%, 36.01 \%$ and $60.17 \%$ for imports.

At the sub regional level, East Africa remains the fastest growing sub region, at $6.1 \%$ in 2017 and $6.2 \%$ in 2018. West Africa's economy grew by 3.2\% in 2018, up from $2.4 \%$ in 2017. According to statistics, the share of ECOWAS exports in global exports was only $0.5 \%$ in 2017. This figure indicates the marginal role played by the region in global trade. According to UNCTAD $(2018)^{12}$ report, countries within ECOWAS globally have an export basket dominated by primary products that are competitive in the global market but in little demand by other African countries. Indeed, the giant Nigeria exports more petroleum products. This export is directed outside the ECOWAS region. Despite, the numerous institutional measures taken by the regional economic communities to promote intra-African trade within the framework of the various regional trade agreements that they have signed. Among them, we can list the customs unions (WAEMU, UDEAC ${ }^{13}$ and $\mathrm{SACU}^{14}$ ). It is clear today that official trade between African countries represents only a small share of their total trade and is tending to stagnate or even decline. Intra-regional trade in Africa remains insignificant compared to their total exports outside the continent.

As regards the monetary cooperation program in ECOWAS, it is set up to accompany a process of monetary integration, the single currency is a currency shared by several states and which replaces national currencies. It allows for the creation of a large integrated market that is conducive to the creation of large companies that can then enter the world market. However, the common currency does not allow for market integration to the same extent as the single currency. Indeed, in terms of monetary sovereignty, in a common currency countries retain their monetary sovereignty. This allows each country to pursue a monetary policy that meets its needs, if it does not harm its partners. The single currency implies a single monetary policy.

\footnotetext{
${ }^{11}$ The North American Free Trade Agreement

12 United Nations Economic Commission for Africa

${ }^{13}$ Central African Customs and Economic Union

${ }^{14}$ The Southern African Custom Union (SACU) is a customs union of five southern African countries established in 1969.
} 
This policy, determined by the community central bank, takes into account the zone as a whole. The monetary geography of ECOWAS includes, on the one hand, the WAEMU countries and Cape Verde, whose currencies are pegged to the euro and then operate according to the principles of the Eco zone, and, on the other hand, the English-speaking countries of West Africa and Guinea, which have independent currencies.

In 1987, the Authority of Heads of State and Government met in Abuja to adopt the ECOWAS Monetary Cooperation Programme (EMCP). The main objective was to achieve a harmonized monetary system through compliance with a set of macroeconomic convergence criteria8 that would lead to the homogenization of the economies of member states. After 1999, the lack of political will and commitment, the lack of uniformity in the adoption of the macroeconomic framework and finally the lack of coordination and harmonization of policies between countries, led to the proposal of a two-track "fast-track" approach. In the first instance, the CMCP envisaged the launch of the WAMZ single currency and in the second instance the merger between WAMZ and WAEMU to launch the ECOWAS single currency. After the Bamako summit in 2000, for the creation of WAMZ whose mandate was to create a common central bank and launch a common currency in 2003, the merger between WAEMU and WAMZ planned for 2004. This single currency project, which was initiated in December 2009 by the member countries of the WAMZ (Ghana, Nigeria, Guinea, Gambia and Sierra Leone) and which hopes to eventually include all ECOWAS countries, was joined by the countries of the CFA zone (Benin, Burkina Faso, Côte d'Ivoire, Guinea-Bissau, Mali, Niger, Senegal and Togo) in June 2013. Mainly due to the inability of WAMZ member countries to meet the convergence criteria, the CFCP has been postponed several times (2003, 2005, 2009, 2013 and 2015), although a strategy emerged in 2005. This strategy advocates moving towards another option, which is to abandon the intermediate stage of the WAMZ single currency by maintaining the creation of a single currency in 2020 for those member countries that meet the first-tier criteria. However, its implementation is proving difficult, as the path to economic convergence is rather complex. Indeed, divergences have arisen due to its peg to the euro, its fixed parity and the failure to meet the convergence criteria ${ }^{15}$. This is why, on 10 February 2020, Nigeria requested a postponement of the launch of the Eco, the single West African currency, theoretically

\footnotetext{
${ }^{15}$ Convergence criteria are the conditions that countries in an area must meet in order to join and remain in Economic and Monetary Union (EMU), i.e. the Eco zone. The five main criteria are price stability, interest rate, public deficits, public debt and exchange rate.
} 
scheduled for 1 July 2020 for the formation of an optimal monetary zone. So what are the theoretical and empirical foundations of an optimal currency area?

\section{Section 3: Methodology}

There are several techniques and methods for assessing regional trade (macroeconomic indicators such as growth and inflation, trade flows and revealed comparative advantages, etc.). Among them, the gravity model is the most suitable to forecast good results between monetary union and bilateral trade, because of its stability and robustness, although it has some criticisms regarding to border effects (common culture, distance, etc.). The gravity model proposed in this paper inspired by the empirical literature on the subject. Indeed, the gravity model continues to be mentioned as a reference model in international economics (Anderson et al, 2016; Glick and Rose, 2016). Several specifications of the gravity equation exist (see Head and Mayer, 2014). In this paper, we chose the following specification $X_{i j}=A^{*} \operatorname{dist}_{i j}^{\beta_{1}}\left(Y_{i}^{*} Y_{j}\right)^{\beta_{2}}$ with $\mathrm{Xij}$ : represents the value of bilateral trade between country $i$ and country $j$.

$Y_{i}$ et $Y_{j}$ are the Gross Domestic Product (GDP) of country i and country j ;

Dist $_{\mathrm{ij}}$ measures the distance between country $\mathrm{i}$ and country $\mathrm{j}$.

$\mathrm{A}, \beta 1$ and $\beta 2$ are coefficients; $\beta 1$ is assumed negative while $\beta 2$ is assumed positive.

The gravity model presented in this work takes the following general form:

$$
\begin{aligned}
\log \left(\mathrm{X}_{\mathrm{ijt}}\right)=\beta_{0} & +\beta_{1} \log \left(\mathrm{PIB}_{\mathrm{it}}\right)+\beta_{2} \log \left(\mathrm{PIB}_{\mathrm{jt}}\right)+\beta_{3} \log \left(\mathrm{POP}_{\mathrm{it}}\right)+\beta_{4} \log \left(\mathrm{POP}_{\mathrm{jt}}\right) \\
& \left.+\beta_{5} \text { Logdist }_{\mathrm{ij}}+\beta_{6} \mathrm{MU}_{\mathrm{ij}}+\beta_{7} \mathrm{OUV}_{\mathrm{ij}}+\beta_{8} \mathrm{LC}_{\mathrm{ij}}+\beta_{9} \operatorname{CEDEAO}_{\mathrm{it}}\right)+\beta_{10} \mathrm{FRONT}_{\mathrm{ij}} \\
& +\beta_{11} \text { Colon. Commun }_{\mathrm{ij}}+\beta_{12} \mathrm{NATDEMu}_{\mathrm{ij}}+\varepsilon_{\mathrm{ijt}}
\end{aligned}
$$

$\mathrm{X}_{\mathrm{ijt}} \mathrm{is}$ the bilateral exports of country $\mathrm{i}$ to country $\mathrm{j}$.

GDPit is the nominal GDP of country $i$ in year $t$.

GDPjt is the nominal GDP of country $\mathrm{j}$ in year $\mathrm{t}$.

POPit is the population of country $i$ in year $t$.

POPij is the population of country $\mathrm{j}$ in year $\mathrm{t}$.

Distij is the distance between countries $i$ and $j$. 
Among the dummy variables, MUij is the variable simulating the sharing of the single currency, taking the value 1 if countries $\mathrm{j}$ and $\mathrm{i}$ belong to the same monetary union, and 0 otherwise.

OUVij is a dummy variable, which is 1 if the countries have both access to the sea, and 0 otherwise.

ECOWASij is the expression of a membership of the trade partners $i$ and $j$ to the same subregional space. This variable takes the value 1 if country $i$ belongs to the ECOWAS space and country j does not. In other words, if both countries belong to the ECOWAS region the modality is 0 .

LCij represents the common official language between the trading partners: taking the value 1 if the countries share the same language, and 0 otherwise.

FRONTij represents the common border between the countries: taking the value 1 if the countries share the same border, and 0 otherwise.

MUij is the variable simulating the sharing of the single currency, taking the value 1 if countries $\mathrm{i}$ and $\mathrm{j}$ share the same currency, and 0 otherwise.

NATDEMuij is the variable measuring the exchange rate regime between trading partners. It is assumed to be flexible (1) between country $i$ and country $j$, if country $i$ belonging to the ECOWAS space has as a trading partner a country $\mathrm{j}$ not belonging to this space and fixed (0) between country $\mathrm{i}$ and country $\mathrm{j}$ belonging to the ECOWAS space.

cijt is the error term.

The originality of this study, compared with previous studies, is to see with what intensity the future single ECOWAS currency and its exchange rate regime could affect the trade of these countries, while using a new more robust estimation technique (PPMLHDFE) and more recent data.

\section{1- The estimation technique and data sources}

The management of the problem of zero flows of the dependent variable has always been a subject of debate in the gravity model literature, as these zero flows lead to a loss of information. The inability of log-linear specifications to deal effectively with this problem has directed the debate towards non-linear specifications, of which Santos-Silva and Tenreyro (2006) propose the log-linear form as a strategy for overcoming the inconsistency arising from the use of OLS. However, due to the presence of heteroskedasticity and zero flows in the dependent variable, the assumption of a lognormal distribution of the error terms of the log-linear model violated. 
Santos-Silva and Tenreyro (2006, 2010, and 2011) recommend the use of the Poisson Pseudo Maximum Likelihood (PPML) estimator in this context. However, in the context of this work, due to the presence of fixed effects, the large number of zero values in the dependent variable and the multiple sources of heteroscedasticity with which the panel data are confronted, we use, contrary to the other authors, a new estimation technique called the

In contrast to other authors, we use a new estimation technique known as the Poisson rapid estimation technique with high-dimensional fixed effects (PPMLHDFE). Indeed, this estimator, according to (Larch et al, 2018), then (Sergio Correia et al., 2019), in addition to taking into account the advantages of the Poisson estimator (PPML), it also has the advantage of controlling several fixed effects. It implements a new and more robust approach to check the existence of (pseudo) maximum likelihood estimates. It also allows controlling multiple sources of heterogeneity while speeding up compared to existing algorithms for non-linear estimation of high-dimensional fixed effects. It also has the advantage of leading to a faster calculation of the parameters of interest while eliminating some unnecessary steps (number of iterations).

The variables used in this work are of two types: quantitative variables and dummy variables. Our sample covers the ECOWAS countries (exporting countries), plus their partners. These partners were choosing according to the trade volume of ECOWAS countries towards these countries. Since 2015, the structure of ECOWAS trade with the rest of the world has been dominated by exports to the European Union (23\%), whose main partners are France, Germany, Italy, Portugal, Spain, Holland, Belgium and the United Kingdom. ECOWAS also has a significant trade volume with the United States, Canada and Mexico (24\%). In addition, there are South Africa, China, Japan, Brazil, India and South Korea (UNCTAD, 2018). To these potential partners, we add the 15 ECOWAS countries to this list, thus making a base with thirty(30) partner countries with the exception of Russia and Belgium due to missing data on independent variables for the study period. 


\section{2-Results of the estimation}

\begin{tabular}{|c|c|c|c|}
\hline $\begin{array}{l}\text { Variables of the } \\
\text { model }\end{array}$ & $\begin{array}{l}\text { Ordinary Least } \\
\text { Squares }\end{array}$ & $\begin{array}{l}\text { Pseudo Poisson Maximum } \\
\text { Likelihood (PPML) }\end{array}$ & $\begin{array}{l}\text { Pseudo Poisson Maximum } \\
\text { Likelihood with high Fixed } \\
\text { Effects (PPMLHDFE) }\end{array}$ \\
\hline Single Currency & $\begin{array}{l}2.095 * * * \\
(0.153)\end{array}$ & $\begin{array}{c}1.057 * * * \\
(0.209)\end{array}$ & $\begin{array}{l}1.057 * * * \\
(0.209)\end{array}$ \\
\hline Opening to the Sea & $\begin{array}{l}0.409 * * * \\
(0.0959)\end{array}$ & $\begin{array}{l}0.567 * * * \\
(0.130)\end{array}$ & $\begin{array}{l}0.567 * * * \\
(0.130)\end{array}$ \\
\hline Common Border & $\begin{array}{l}0.650 * * * \\
(0.138)\end{array}$ & $\begin{array}{c}0.205 \\
(0.203)\end{array}$ & $\begin{array}{c}0.205 \\
(0.203)\end{array}$ \\
\hline Common colonist & $\begin{array}{l}-1.114 * * * \\
(0.186)\end{array}$ & $\begin{array}{l}0.380^{*} \\
(0.199)\end{array}$ & $\begin{array}{r}0.380^{*} \\
(0.199)\end{array}$ \\
\hline Common Language & $\begin{array}{l}0.813 * * * \\
(0.147)\end{array}$ & $\begin{array}{c}0.236 \\
(0.147)\end{array}$ & $\begin{array}{l}0.236 \\
(0.147)\end{array}$ \\
\hline Ecowas & $\begin{array}{l}-0.365 \\
(0.289)\end{array}$ & $\begin{array}{c}-0.910 * * * \\
(0.319)\end{array}$ & $\begin{array}{l}-0.910 * * * \\
(0.319)\end{array}$ \\
\hline Single currency's Nat & $\begin{array}{l}0.747 * * * \\
(0.261)\end{array}$ & $\begin{array}{c}2.037 * * * \\
(0.276)\end{array}$ & $\begin{array}{l}2.037 * * * \\
(0.276)\end{array}$ \\
\hline $\mathrm{Ln}(\mathrm{PIBi})$ & $\begin{array}{l}1.333 * * * \\
(0.0517)\end{array}$ & $\begin{array}{l}1.008 * * * \\
(0.0742)\end{array}$ & $\begin{array}{l}1.008 * * * \\
(0.0742)\end{array}$ \\
\hline Ln (POPj) & $\begin{array}{l}0.545 * * * \\
(0.0338)\end{array}$ & $\begin{array}{c}0.696 * * * \\
(0.0499)\end{array}$ & $\begin{array}{l}0.696 * * * \\
(0.0499)\end{array}$ \\
\hline $\operatorname{Ln}(\mathrm{PIBj})$ & $\begin{array}{l}-0.0111 \\
(0.0116)\end{array}$ & $\begin{array}{l}-0.0530 * * * \\
(0.0133)\end{array}$ & $\begin{array}{c}-0.0530 * * * \\
(0.0133)\end{array}$ \\
\hline $\mathrm{Ln}(\mathrm{POPi})$ & $\begin{array}{l}-0.179 * * * \\
(0.0438)\end{array}$ & $\begin{array}{l}0.00624 \\
(0.0827)\end{array}$ & $\begin{array}{l}0.00624 \\
(0.0827)\end{array}$ \\
\hline Ln (distance) & $\begin{array}{l}-0.953 * * * \\
(0.0852)\end{array}$ & $\begin{array}{l}-1.226 * * * \\
(0.111)\end{array}$ & $\begin{array}{c}-1.226 * * * \\
(0.111)\end{array}$ \\
\hline Constant & $\begin{array}{l}-28.91 * * * \\
(1.235)\end{array}$ & $\begin{array}{l}-22.44 * * * \\
(1.412)\end{array}$ & $\begin{array}{l}-22.44 * * * \\
(1.412)\end{array}$ \\
\hline $\begin{array}{l}\text { Observations } \\
\text { R-squared }\end{array}$ & $\begin{array}{l}4,497 \\
0.385\end{array}$ & $\begin{array}{l}4,497 \\
0.622\end{array}$ & $\begin{array}{l}4,497 \\
0.7830\end{array}$ \\
\hline
\end{tabular}

Source: Author, based on Stata 14 software $* * * p<0.01, * * p<0.05, * p<0.1$

The best estimator retained is the Pseudo Poisson Maximum Likelihood with Large Fixed Effects (PPMLHDFE) due to the significance of the variables of interest and the high Rsquared. 


\section{Section 4: Discussion of results and policy implications}

The results of our econometric estimations, presented in the table above, show that our model is globally significant (Prob>chi2 $=0.000$ ). Indeed, with the exception of the traditional variable 'common settler' which is significant at the $10 \%$ level, the other variables are significant at the $1 \%$ level, except for the variables 'common language' and 'common border' which are not significant. All estimated coefficients are statistically significant at the $1 \%$ level. The coefficients of the variables for the exporting country (ECOWAS country), the partner country (ECOWAS country) and the partner country (ECOWAS country) are significant and their signs are in line with the expected ones. The coefficients associated with the variables gross domestic product of the exporting country (ECOWAS country), the partner country (ECOWAS country and other partners) and distance are elasticities. The coefficient associated with the GDP of the exporting country (ECOWAS country) indicates at a significance level of $1 \%$, all other things being equal, that a $10 \%$ increase in the GDP of this country generates an increase of more than $10 \%$ in the export trade of ECOWAS. This result is in line with many other studies, including (Buongiorno, 2015and Mbouandi Njikam and Avom, 2013). This confirms the idea that the higher the per capita income of a country, the greater the production capacity and the volume of goods available for export. This result also indicates the country's ability to produce and export at lower costs, all other things being equal. In contrast, the effect of GDP on the importing country's trade is negative and significant. Clearly, the higher the GDP of the importing country, the lower the elasticity of demand for goods from abroad. Specifically, a $1 \%$ increase in the GDP of the importing country leads to a decrease of more than $0.050113 \%$ in trade. Our results are in agreement with those of (Avom, D. and Mignamissi, D., 2013). For them, when it comes to imports, the population of this country is a good indicator of market size that can absorb local products at lower cost. Similarly, the presence of galloping inflation in the country can discourage economic operators in importing countries, who fear importing this negative shock into their economies. A substitution effect of imported goods by domestic goods will take place in the partner countries, even if the latter are of inferior quality. Partner countries consume more of the local products they import. The analysis of the econometric results shows that, at the $1 \%$ threshold, a $1 \%$ increase in the population of the partner country results in a $0.696 \%$ increase in trade. Indeed, the larger the population of the destination country, the higher the bilateral trade. This positive sign for the population of the importing country would mean that the latter is productive and oriented towards the consumption of products, thus a factor increasing bilateral trade (Mignamissi, D., 2018). 
Our hypothesis on distance is true. The effect of distance on trade is negative as predicted. Intraregional trade decreases with increasing distance. Its coefficient is negative and significant at $1 \%$. Countries that are far away trade less than those that are closer together. Similar to Coulibaly, D. et al. (2018) and Kothoni, R. et al (2019), our results show that a 1\% increase in distance between two countries leads to a decrease in their bilateral trade of about $1.23 \%$. This weakness could be because of the facilities offered by the global digital environment to modernize trade structures.

Similarly, the simultaneous opening to the sea positively affects trade between countries as predicted. This dummy variable has a positive and significant coefficient at $1 \%$. Like many other authors (Baita, K., 2019; Gnimassoun, B and Mignon, 2018), we find that openness to the sea increases trade between countries 0.7621 times $\left(e^{0,5665587}-1\right)$.

The single currency, our variable of interest $(\mathrm{Mu})$ that captures the use of the same currency positively and significantly affects trade. This confirms the hypothesis of (Rose A. K., 2000). We obtain that an adoption of the single currency would improve ECOWAS bilateral trade flows by about 1.88 times. This is very much in line with studies by (Sadeh,T., 2014, Glick, and Rose, 2016 and Mika.and Zymek, 2018).

Regarding to our second variable of interest, on the exchange rate regime (flexibility), designed to capture the effect that the flexible regime of this single currency would have on trade, if adopted, seems to have a positive effect on trade of the countries in the zone. In contrast to (Geldi, K., 2012) who finds that exchange rate, variability has no significant impact on bilateral trade. We arrive at almost the same result as (Senadza and Diaba, 2018). For them, exchange rate flexibility has a negative effect on trade in the short run and a positive effect in the long run. The result of our study indicates a positive and significant coefficient at $1 \%$. The adoption of a flexible exchange rate by ECOWAS countries towards their partners increases trade by 6.665 times.

\section{- The policy implications}

The coefficients associated with the variables of the gravity model are mostly significant and also show the expected signs. These results lead us to formulate the following two main policy implications:

First, the significant influence of the single currency sharing on trade would indicate that a single currency area should, other things being equal, increase the intensity of intra-regional 
trade considerably. This answers our question as to whether or not sharing a single currency is a determinant of increased trade within the ECOWAS region. In this regard, we recommend that member states to accelerate reforms relating to the harmonization of macroeconomic policies, presupposing convergence of budgetary and monetary policies (compliance with the convergence criteria), prior to the monetary union stage.

Finally, one of our recommendations concerns the exchange rate of the single currency. We recommend the adoption of a semi-flexible exchange rate regime in the first instance and in the long term a flexible exchange rate regime (gradual approach). Indeed, a flexible exchange rate could have positive effects on growth, thus on employment and the balance of trade. The evolution of the exchange rate remains for the WAEMU countries as well as for speculators and industrialists, a subject of perplexity, and a source of fragility in the future. These countries are indebted and indebted enough, and therefore vulnerable. A rise in commodity prices will create Dutch disease effects and lead to an appreciation of the real effective exchange rate (rise in the prices of tradable compared to non-tradable) and to a loss of competitiveness of the economy: this amplifies the pessimistic vision of countries in the adoption of the flexible exchange rate regime linked to other currencies. To this, it must add the sensitivity of household purchasing power to unanticipated inflation, which leads to a deterioration of the trade balance. 


\section{CONCLUSION}

The progress of regional integration in ECOWAS has led to the desire to create an optimal currency area. This stage of regional integration has given rise to a wave of divergent views on its effect and exchange rate regime on trade. On the one hand, WAMZ countries want to adopt it with a flexible exchange rate, while on the other hand, WAEMU countries want to adopt a fixed exchange rate pegged to the euro. This divergence of views is the central point of our problem, especially when we know that its adoption has effects on the trade of countries. The question addressed by the evaluation of the potential effect that sharing a single currency would have had on integration through the ECOWAS market, allowed us to identify several factors that influence trade. To achieve this, we used a gravity model following the latest developments from Head and Mayer (2014). The variables of distance, growth domestic product, population, exchange rate regime, openness to the sea, common settler, common border, common language and community membership, nature of the single currency, and single currency simulating the sharing of a single currency by REC member countries were selected. The present panel study based on data from the World Bank (WDI), the IMF (DOTS) and CEPII from 2009 to 2018. We estimate our equation by the Pseudo Maximum Poisson with high fixed Effects (PPMHDFE). We find out three main results: (i) the potential effect of the single currency on bilateral trade is significant; robustness tests confirm the positive effect that currency sharing would have had on trade; (ii) a flexible exchange rate could have positive effects on trade (iii) distance is a factor limiting trade. In the meantime, we invite ECOWAS countries to make efforts to meet the convergence criteria in order to be the foundation of the single African currency. However, our study has some shortcomings, notably the lack of recent data to better express the reality. In addition, several other methods exist to quantify the nature of the exchange rate regime of the single currency.

\section{*Availability of Data and Materials}

Our data extracted from the World Bank WDI database (nominal GDP and population), the IMF (DOTS) data (exports and imports) and the CEPII database (distance) and from Google Earth (common language, common border, opening to the sea, common settlement and single currency). The period of study chosen is 2009-2018, mainly because of the date on which the single currency was initially planned to be introduced within ECOWAS (December 2009) and because of the availability of data on the dependent variable, which is total bilateral exports. 


\section{*Competing Interests}

Not applicable

\section{*Funding}

Not applicable

\section{*Author's contributions}

Not applicable

\section{*List of abbreviations}

ASEAN: Association of Southeast Asian Nations

AU: African Union

DOTS: Direction of Trade Statistics - IMF Data

ECOWAS: Economic Community of West African States

EMCP: Monetary Cooperation Programme

GDP: Gross Domestic Product

IMF: International Monetary Fund

OAU: Organization of African Unity

OMZ: Optimal Monetary Zone

PPML: Pseudo Maximum Poisson Likelihood

PPMHDFE: Pseudo Maximum Poisson Likelihood with High Dimension Fixed Effects

UNCTAD United Nations Conference on Trade and Development

WAEMU West African Economic and Monetary Union

WAMZ: West African Monetary Zone

WDI: World Development Indicators

\section{*Acknowledgments}

I acknowledge the African Union and the Panafrican University for giving the scholarship opportunity. Acknowledgements are also due to Professor Henri Ngoa Tabi for teaching me article-writing structure.

\section{*Authors' Information}

Not applicable 


\section{REFERENCES}

Candau et Rey. (2014). The effect of the euro on aeronautic trade: A French regional analysis. Modélisation économique , Elsevier, 41 (C), 345-355.

Miron et al. (2013). Estimating the Effect of Common Currencies on Trade: Blooming or Withering Roses? Economics and Finance.

Sergio Correia et al. (2019). Verifying the existence of maximum likelihood estimates. arXiv: 1903.01633 [econ.EM].

Agbodji, A. E. (2007). Intégration et échanges commerciaux intra sous-régionaux: le cas de l'UEMOA. Revue africaine de l'intégration, 1(1).

Alesina et al. (2002). Optimal Currency Areas. National Bureau Of Economic Research.

Alhassan et Payaslioglua. (2019). Institutions and bilateral trade in Africa: an application of Poisson's estimation with high-dimensional fixed effects to structural gravity model. Economics Letters.

Anderson et Yotov. (2010). The Changing Incidence of Geography. American Economic Review.

Anderson J. E. et van Wincoop E. (2003). Gravity With Gravitas: A Solution to the Border Puzzle. American Economic Review, 93(1), 170-192.

Anderson J.E. (2011). The Gravity Model. Annual Review of Economics,, 3, 133-160.

Anderson, J. E. et al. (2016). Gravity with Scale Effects. Journal of International Economics, $100,174-193$.

Anderson, J.E. (1979). A Theoretical Foundation for the Gravity Equation. American Economic Review, 69, 106-116.

Anyanwu, J. C. (2003). Estimating the Macroeconomic Effects of Monetary Unions: The Case of Trade and Output. African Development Review, 15( 2-3), 126-145.

Auray et al. (2013). The effect of a common currency on the volatility of the extensive margin of trade. Journal of International Money and Finance, 31, Issue 5, , 1156-1179.

Avom, D. (2005). Les déterminants des échanges dans la CEMAC : une évaluation empirique. Économie appliquée, 58(2), 127-153.

Avom, D. et Mignamissi, D. (2013). Evaluation et analyse du potentiel commercial dans la CEMAC. L'Actualité Economique, Revue d'Analyse Economique, Vol. 89(No. 2), $115-145$.

BAD. (2018). Banque Africaine de Développement (2018), Rapport annuel .

Baita, K. (2019). Intégration régionale et échanges commerciaux : Une analyse empirique dans les pays de la Communauté Economique des Etats de l'Afrique de l'Ouest'.

Balassa, B. (1961). Towards a theory of economic integrations. . Kyklo, 14(1), 1-17. 
Baldwin, R. (1993). The Potential for Trade Between the Countries of EFTA and Central and Eastern Europe EFTA Occasional Paper. Genève: European Free Trade Association, 44.

Bénassy-Quéré A. et Coupet, M. (2005). On the adequacy of exchange rate arrangements in Sub-Saharan Africa. World Economy, 28(3), 349-373.

Buongiorno. (2015). Monetary union and forest products trade-The case of the euro. Journal of Forest Economics, 238-249 .

Carrère. (2004). African Regional Agreements: Impact on Trade with or without Currency Unions. Journal of African Economies, 13, Issue 2, , 199-239.

Carrère. (2004). African Regional Agreements: Impact on Trade with or without Currency Unions. Journal of African Economies, Volume 13, Issue 2, 199-239.

Carrère. (2013). UEMOA, CEMAC : quelle performance en matière de commerce ? Revue d'économie du développement, 21, 33-60.

CEDEAO. (2019). RAPPORT DE CONVERGENCE MACROECONOMIQUE.

Cindea Iuliana et Cindea Moise. (2012). The euro effect on international trade, '. Social and Behavioral Sciences, 58, 1267-127.

CNUCED. ( 2016). Indice de l'intégration régionale en Afrique Rapport 2016.

CNUCED. (2016). Rapport économique sur l'Afrique.

CNUCED. (2018). Rapport sur le commerce et le développement.

CNUCED. (2018). Rapport sur le commerce et le développement 2018.

Condé, L. (2012). Thèse de Doctorat, Trois essais sur la monnaie unique de la CEDEAO et les défis associés.

Couharde, C. et al. (2013). Revisiting the Theory of Optimum Currency Areas: Is the CFA Franc Zone Sustainable?', , , pp. Journal of Macroeconomics, Vol. 38, Part B, 428441.

Coulibaly, D. et al. (2018). Growth-enhancing effect of openness to trade and migrations: What is theeffective transmission channel for Africa? Journal of African Economics, 27(4), 369-404.

Crola, Jean-Denis. (2019). Sahel : lutter contre les inégalités pour répondre aux défis du développement et de la sécurité. DOCUMENT D'INFORMATION D'OXFAM.

De Sousa, J. (2012). The Currency Union Effect on Trade Is Decreasing over Time. Economics Letters, 117(3), 917-920.

Deardorff, A. (1998). The Regionalization of the World Economy. in Jeffrey A. Frankel . University of Chicago Press.

Dorn et al. (2013). Fixed currency regimes and the time pattern of trade effects. Economics Letters, 119(2), 120-123. 
Dorn, Peter et Egger H. (2013). Fixed currency regimes and the time pattern of trade effects. Economics Letters.

Eaton, J. and Kortum, S. (2001). Trade In Capital Goods. European Economic Review, 45, 1195-1235.

Evenett S. J. et Keller W. (2002). On Theories Explaining the Success of The Gravity Equation. Journal of Political Economy, 281-316.

Fontagné et al. (2002). Potentiels de commerce entre économies hétérogènes : un petit mode d'emploi des modèles de gravité. La Documentation française | «Économie \& prévision »(152-153), 115 à 139.

Frankel et Rose. (2002). Estimating the Effect of Currency Unions on Trade and Output. NBER Working Paper(7857).

Frankel, J. A. et A. K. Rose. (1998). The Endogeneity of the Optimum Currency Area Criteria', ,. The Economic Journal, 108(449), 1009-1025.

Friedman. (1953). Essays in Positive Economics "The Methodology of Positive Economics". University of Chicago Press, 3-43.

Geldi, K. (2012). Trade effects of regional integration: A panel cointegration analysis. Economic Modelling.

Glick, R. et A. K. Rose. (2016). Currency Unions and Trade:APost-EMU Reassessment. European Economic Review, 87.

Gnimassoun, B et Mignon. (2018). Regional Integration: Do Intra-African Trade and Migration Improve Income in Africa? International Regional Science Review, 1-45.

Haas, Ernst B. (1964). Beyond the Nation State: Functionalism and International.

Haas, Ernst B. (1968). The Uniting of Europe: Politics, Social and Economic Forces, 19501957, second edition. Stanford, CA: Stanford University Press.

Hausman. (1978). Specification Tests in Econometrics. The Econometric Society, Vol. 46, (No. 6 ), 1251-1271.

Head, K. et Mayer,T. (2014). Gravity Equations: Workhorse, Toolkit, and Cookbook', in G. Gopinath, E. Helpman and K. Rogoff (eds.). Handbook of International Economics, Vol. 4.

Hove S., A. Touna Mama, F. Tchana Tchana. (2015). 'Monetary Policy and Commodity Terms of Trade Shocks in Emerging Market Economies. Economic Modelling, 49, 5371.

Johnson H.G. (1970). Further Essays in Monetary Theory. Harvard University Press.

Katayama et Melatos. (2011). The nonlinear impact of currency unions on bilateral trade. Economics Letters, 112, Issue 1, 94-96.

Kaufmann, Hugo M. (1997). L'Union économique et monétaire européenne: une expérience dont le temps est venu ou l'a fait? Archive of regional integration. 
Kenen, P. B. (1969). The Optimum Currency Area: An Eclectic View', in R. A. Mundell et A. K. Swoboda (eds.), Monetary Problems of the International Economy. University of Chicago Press, .

Kenen, P.B. (1969). The Theory of Optimum Currency Areas: An Eclectic View, " in Monetary Problems of theInternational Economy, ed. by R.A. Mundell and A.K. Swoboda. Chicago: Chicago University Press.

Kindelberger, C. (1989). International Public Goods without International Government. American Economic Review, 76, 1-13.

Kothoni, R. et al. (2019). Potentiel d'expansion des échanges commerciaux entre les pays d'Afrique de l'Ouest. Observatoire de la Francophonie économique, OFE-RP no.1.

Krugman, P. (1993). On the Relationship Between Trade Theory and Location Theory. Review of International Economics, 1, 110-122.

Lafuente, J. A., R. Perez et J. Ruiz. (2016). Monetary Policy Regimes and the Forward Bias for Foreign Exchange. Journal of Economics and Business, 13-28.

Larch et al. (2018). Currency Unions and Trade: A PPML Re-assessment with Highdimensional Fixed Effects. oxford bulletin of economics and statistics, doi: 10.1111/obes.12283.

Lavergne, P., et Rostow, W. ((1997)). Les étapes de la croissance économique: un manifeste non communiste. Economica.

Mbouandi Njikam et Avom. (2013). L'intégration par le Marché cas des Pays de la CEEAC', article. LAREA-FSEG Université de Yaoundé II-Cameroun.

McCallum, J. (1995). National Borders Matter: Canada-US Regional Trade Patterns. American Economic Review, 85(3), 615-623.

McKinnon, R. I. (1963). Optimum Currency Areas. American Economic Review, 52, $717-$ 725.

McKinnon, R. I. (1963). Optimum Currency Areas. American Economic Review, 52, $717-$ 725.

Meade J. (1955). The theory of customs unions. North-Holland Publishing Company, 1.

Meade, J. (1955). The theory of customs unions. North-Holland Publishing Company., Vol 1.

Mignamissi, D. (2018). Monnaie unique et intégration par le marché en Afrique: le cas de la CEEAC et de la CEDEAO. African Development Review, 30(1), 71-85.

Mika, A.et Zymek, R. (2018). Friends without benefits? New EMU members and the "Euro Effect" on trade. Journal of International Money and Finance.

Miron et al. (2013). Estimating the Effect of Common Currencies on Trade: Blooming or Withering Roses? Economics and Finance.

Mishkin, F. (2013). Monnaie, banque et marchés financiers. Nouveaux Horizons.

Mitrany, D. (1943). A Working Peace System,. 
Mohsen \& Kanitpong, T. (2019). Thailand-China commodity trade and exchange rate uncertainty: Asymmetric evidence from 45 industries. The Journal of Economic Asymmetries, 20(C).

MORAVCSIK, Andrew. (1991). Negociating the Single European Act. National interests and Conventional Statecraft in the European Community. International Organization, 45(1), 19- 56.

Mucchielli, J.-L. et Mayer, T. (2005). 'Economie Internationale. Hyper Cours édition Dalloz.

Mundell, R. A. (1961). A Theory of Optimum Currency Areas. American Economic Review(51), 657-665.

OMC. (2011). Rapport sur le commerce mondial.

OMC. (2015). L’intégration du commerce en vue de la réalisation des Objectifs de développement durable. L'intégration.

Plumber et Troeger. (2007). Efficient Estimation of Time-Invariant and Rarely Changing Variables in Finite Sample Panel Analyses with Unit Fixed Effects. Political Analysis, 124-139.

Qing He et al. (2019). Does Currency Matter for Regional Trade Integration? International Review of Economics \& Finance.

Rose, A. K. (2000). One Money, One Market, Estimating the Effect of Common Currencies on Trade. Economic Policy, 30, 9-45.

Rose, A. K. (2001). Currency Unions And Trade: The Effect Is Large. Economic Policy: A European Forum, 33(10), 449-457.

Sadeh,T. (2014). The Euro's Effect on Trade. European Union Politics, 15(2), 215-234.

Santana-Gallego et Jorge, V.-R. (2019). International trade, exchange rate regimes, and financial crises. North American Journal of Economics and Finance.

Santana-Gallegos et Pérez-Rodríguez, J. (2019). International trade, exchange rate regimes, and financial crises. North American Journal of Economics and Finance.

Santos Silva, JMC et S. Tenreyro. (2006). 'The Log of Gravity. Review of Economics and Statistics, 88(4), 641-658.

Santos Silva, JMC et S. Tenreyro. (2010). Currency Unions in Prospect and Retrospect. Annual Review of Economics, 2, 51-74.

Santos Silva, JMC et S.Tenreyro. (2011). Further Simulation Evidence on the Performance of the Poisson Pseudo-Maximum Likelihood Estimator. Economics Letters, 112(2), 220222.

Schmitter, Philippe C. (1971). A Revised Theory of Regional Integration', in Lindberg, Leon N. and Scheingold, Stuart A. (eds) Regional Integration: Theory and Research. Cambridge, MA: Harvard University Press, 232-264. 
Senadza et Diaba. (2018). Effect of exchange rate volatility on trade in Sub-Saharan Africa. Journal of African Trade, Volume 4, Issue 1-2, 20 - 36.

Sorgho, Z. (2013). Modèle gravitationnel appliqué au commerce: Une «success story» dans l'étude des déterminants des flux commerciaux bilatéraux - Vue d'ensemble sur le modèle Fondation Pour Les Etudes Et Recherches Sur Le Développement International | F.

Tavlas. (1994). The theory of monetary integration. Open Economies Review, 'Springer,, $5(2), 211-230$.

Tinbergen, J. (1962). An Analysis of World Trade Flows, in Shaping the World Economy. New York, NY: Twentieth Century Fund.

Tsangarides, C. et al. (2006). Stylised Facts on Bilateral Trade and Currency Unions: Implications for Africa. IMF Working Paper, WP/06/31.

Tsangarides, C. G. et M. S. Qureshi. (2008). Monetary Union Membership in West Africa: A Cluster Analysis. World Development, 36(7), 1261-1279.

Viner, J. (1950). The economics of customs unions. The customs union issue.

Viner, J. (1950). The economics of customs unions. The customs union issue.

Zhao, X. et Kim,Y. . (2009). Is the CFA Franc Zone an Optimum Currency Area? World Development, 37(12), 1877-1886. 
Annex

\begin{tabular}{|c|c|c|c|}
\hline Countries & Institut of emission & Currency & Foreign exchange regime \\
\hline $\begin{array}{l}\text { Benin } \\
\text { Burkina Faso } \\
\text { Côte d'Ivoire } \\
\text { Guinea Bissau } \\
\text { Mali } \\
\text { Niger } \\
\text { Senegal } \\
\text { Togo }\end{array}$ & $\begin{array}{l}\text { Central Bank of West } \\
\text { African States }\end{array}$ & CFA (XOF) & $1 \mathrm{EUR}=655,957 \mathrm{XOF}$ \\
\hline Cape Verde & $\begin{array}{l}\text { Central Bank of Cape } \\
\text { Verde }\end{array}$ & Escudo (CVE) & $1 \mathrm{EUR}=110,265 \mathrm{CVE}$ \\
\hline Gambia & Central Bank of Gambia & Dalasi (GMD) & $\begin{array}{l}\text { Flexible exchange } 1 \text { EUR }= \\
55,1372 \text { GMD }\end{array}$ \\
\hline Ghana & Banque of Ghana & Cedi (GHS) & $\begin{array}{l}\text { Flexible exchange } 1 \text { EUR }= \\
6,21704 \text { GHS }\end{array}$ \\
\hline Guinea & $\begin{array}{l}\text { Central Bank of Republic } \\
\text { of Guinea }\end{array}$ & $\begin{array}{l}\text { Guinea Franc } \\
(\mathrm{GNF})\end{array}$ & $\begin{array}{l}\text { Flexible exchange } \\
1 \mathrm{EUR}=10.247,4 \mathrm{GNF}\end{array}$ \\
\hline Liberia & Central Bank of Liberia & $\begin{array}{l}\text { Liberian Dollar } \\
\text { (LRD) }\end{array}$ & $\begin{array}{l}\text { Flexible exchange } \\
1 \mathrm{EUR}=214,676 \mathrm{LRD}\end{array}$ \\
\hline Nigeria & Central Bank of Nigeria & Naira (NGN) & $\begin{array}{l}\text { Flexible exchange } \\
1 \mathrm{EUR}=419,412 \mathrm{NGN}\end{array}$ \\
\hline Sierra Leone & Banque of Sierra Leone & Leone (SLL) & $\begin{array}{l}\text { Flexible exchange } \\
1 \mathrm{EUR}=10.382,9 \mathrm{SLL}\end{array}$ \\
\hline
\end{tabular}

